\title{
Pendampingan Belajar Siswa Melalui Pembelajaran Multimodal Untuk Meningkatkan Kemampuan Siswa Di Masa Pandemi Covid-19
}

\author{
Riza Faishol ${ }^{1}$, Imam Mashuri ${ }^{2}$, Eka Ramiati ${ }^{3}$, Idi Warsah ${ }^{4}$, Hikmah Nur \\ Laili $^{5}$ \\ 1,2,3,5Institut Agama Islam (IAI) Ibrahimy Genteng Banyuwangi \\ ${ }^{4}$ Institut Agama Islam Negeri (IAIN) Curup Bengkulu \\ ${ }^{1}$ riezha09@gmail.com ${ }_{2}^{2}$ mashuri5758.aba@gmail.com, ${ }^{3}$ numateraeka@gmail.com, \\ 4idiwarsah@iaincurup.ac.id, 5hikmahnurlaili04@gmail.com
}

Submitted: 2021-02-16 | Revised: 2021-06-24 | Accepted: 2021-06-24

\begin{abstract}
This devotional activity is motivated by the number of parents who cannot accompany their children to learn from home during the pandemic for various reasons and occupations. Another obstacle is that students are unable to understand the subject matter independently, the support facilities are lacking, some students and parents cannot operate gadgets, there are even students who do not have gadgets that hinder in following online learning. Therefore, this student learning mentoring is done with the aim to increase the activeness, creativity, and confidence of students in learning. The method of implementation of mentoring is carried out in several stages, namely preparation, implementation of mentoring, and evaluation. With this innovation of multimodal learning, it is proven to be very helpful for students who were previously quiet, shy, and lacking confidence. After participating in this mentoring process, the participants become more active, creative, and have high confidence.
\end{abstract}

Keywords: Learning Innovation, Multimodal Learning, Student Creativity, Covid-19 Pandemic

Abstrak. Kegiatan pengabdian ini dilatar belakangi karena banyaknya orang tua siswa yang tidak bisa mendampingi anaknya untuk belajar dari rumah selama masa pandemi karena berbagai alasan dan pekerjaan. Kendala lainnya adalah siswa tidak mampu memahami materi pelajaran secara mandiri, dukungan fasilitas yang kurang, beberapa siswa dan orang tua tidak dapat mengoperasikan gadget, bahkan ada siswa yang tidak memiliki gadget sehingga menghambat dalam mengikuti pembelajaran daring. Oleh karena itu, pendampingan belajar siswa ini dilakukan dengan tujuan untuk meningkatkan pemahaman, keaktifan, kreativitas, dan kepercayaan diri siswa dalam pembelajaran. Metode pelaksanaan pendampingan dilakukan dalam beberapa tahapan, yaitu persiapan, pelaksanaan pendampingan, dan evaluasi. Dengan adanya inovasi pembelajaran multimodal ini, terbukti sangat membantu siswa yang sebelumnya 
pendiam, pemalu, serta kurang percaya diri. Setelah mengikuti proses pendampingan ini siswa peserta menjadi lebih aktif, kreatif, dan memiliki rasa percaya diri yang tinggi.

Kata Kunci: Inovasi Belajar, Pembelajaran Multimodal, Kreativitas Siswa, Pandemi Covid-19

\section{Pendahuluan}

Pendidikan adalah salah satu faktor yang sangat menentukan dan berpengaruh terhadap perubahan sosial. John Dewey menyatakan bahwa pendidikan sebagai salah satu kebutuhan, fungsi sosial sebagai bimbingan, sarana pertumbuhan yang mempersiapkan dan membukakan serta membentuk disiplin hidup. ${ }^{1}$ Pendidikan tidak hanya mencakup pengembangan intelektualitas saja, akan tetapi lebih ditekankan pada proses pembinaan kepribadian anak didik secara menyeluruh sehingga anak menjadi dewasa. ${ }^{2}$

Pandemi covid-19 yang terjadi di hampir seluruh belahan dunia sangat mengguncang stabilitas kehidupan, tidak terkecuali dalam bidang pendidikan. Di Indonesia, pemerintah telah mengeluarkan kebijakan-kebijakan untuk mencegah penyebaran virus covid-19. ${ }^{3}$ Salah satunya yaitu kebijakan untuk bekerja, beribadah, dan belajar dari rumah atau yang di kenal dengan istilah "work from home". Dengan demikian segala aktivitas apapun dilakukan di dalam rumah, tak terkecuali aktivitas belajar-mengajar. Dengan adanya penutupan sekolah tersebut, memaksa siswa dan guru untuk tetap melakukan proses pembelajaran menggunakan sistem online. ${ }^{4}$ Pembelajaran online yaitu kegiatan belajar mengajar yang dilaksanakan melalui jaringan internet dengan memanfaatkan perangkat teknologi informasi dan komunikasi antara lain komputer, laptop maupun bandphone. Hal tersebut seperti hasil penelitian Handarini dkk yang menyatakan

1 Andrianto Andrianto, "Implementasi Komunikasi Edukatif Dalam Pemaduan Iman, Ilmu Dan Amal Studi Pembelajaran Pai Di Sma It Abu Bakar Yogyakarta," Tarbiyatuna: Kajian Pendidikan Islam 3, no. 2 (September 29, 2019): 89-105, https://doi.org/10.29062/tarbiyatuna.v3i2.261.

2 Krismawati Krismawati, Idi Warsah, and Ummul Khair, "Implementasi Pendekatan Kontekstual Dalam Pembelajaran PAI di Sekolah Dasar," Jurnal Elementaria Edukasia 3, no. 2 (October 22, 2020), https://doi.org/10.31949/jee.v3i2.2262; Idi Warsah and Nuzuar Nuzuar, "Analisis Inovasi Administrasi Guru Dalam Meningkatkan Mutu Pembelajaran (Studi Man Rejang Lebong)," Edukasi 16, no. 3 (2018): 294572; Idi Warsah, "Pendidikan Keimanan Sebagai Basis Kecerdasan Sosial Peserta Didik: Telaah Psikologi Islami," Psikis: Jurnal Psikologi Islami 4, no. 1 (2018): 1-16.

${ }^{3}$ Julia Elisvi et al., "Analisis Pemanfaatan Media Pembelajaran Online di SMK IT Rabbi Radhiyya Masa Pandemi Covid-19," Al-Tarbawi Al-Haditsab: Jurnal Pendidikan Islam 5, no. 2 (December 17, 2020), https://doi.org/10.24235/tarbawi.v5i2.6721; Jessika Tamara et al., "Strategi Pembelajaran Dosen Melalui Pemanfaatan Media Whatsapp Di Masa Pandemi COVID-19," At-Ta'lim : Media Informasi Pendidikan Islam 19, no. 2 (December 30, 2020): 351-73, https://doi.org/10.29300/attalim.v19i2.3372.

4 Tamara et al., "Strategi Pembelajaran Dosen Melalui Pemanfaatan Media Whatsapp Di Masa Pandemi COVID-19." 
bahwa pembelajaran daring menjadi salah satu keberhasilan untuk menciptakan perilaku social distancing sehingga meminimalisir munculnya keramaian yang dianggap dapat berpotensi semakin menyebarnya covid-19 di lingkungan sekolah. ${ }^{5}$

Tetapi, dalam pelaksanaannya masih banyak kendala, seperti ketidakmerataan akses terhadap teknologi yang membuat para siswa sulit mendapat materi pembelajaran dan ketidaksiapan orang tua dalam membimbing anaknya belajar. ${ }^{6}$ Hal ini selaras dengan hasil penelitian Handayani dkk bahwa dalam pelaksanaan pembelajaran dengan moda daring terdapat beberapa kendala yakni keterbatasan interaksi guru dalam menjelaskan materi sehingga banyak siswa yang tidak paham, ketidaksiapan orang tua dalam membimbing anaknya dalam belajar. ${ }^{7}$ Kelemahan dalam pelaksanaan pembelajaran daring adalah kurang maksimalnya keterlibatan siswa dalam pembelajaran. ${ }^{8}$

Hasil wawancara yang dilakukan oleh mahasiswa peserta Kuliah Kerja Nyata dengan beberapa wali murid di Dusun Yosowinangun RT 05 RW 03 Desa Jajag Kecamatan Gambiran Kabupaten Banyuwangi menunjukkan bahwa selama masa pandemi berlangsung dan sekolah dialihkan ke rumah, banyak orang tua siswa yang merasa berat dan kesulitan dalam mendampingi belajar anak-anaknya. Sehingga banyak orang tua yang membiarkan anaknya belajar sendiri, akibatnya anak-anak mereka lebih banyak bermain daripada belajar. Kendala lain adalah siswa tidak mampu memahami materi pelajaran secara mandiri, siswa merasa jenuh dan bosan selama kegiatan pembelajaran berlangsung, dukungan fasilitas yang kurang memadai, beberapa siswa dan orang tua tidak dapat mengoperasikan gadget, bahkan ada siswa yang tidak memiliki gadget sehingga menghambat dalam mengikuti pembelajaran daring.

Inovasi merupakan pembaharuan yang sejatinya ditujukan untuk memecahkan permasalahan tertentu. ' Santoso S. Hamijoyo mengemukakan bahwa inovasi pendidikan adalah suatu perubahan baru yang berbeda dari hal

${ }^{5}$ Tri Handayani, Hariyani Nur Khasanah, and Rolisda Yoshinta, "Pendampingan Belajar Di Rumah Bagi Siswa Sekolah Dasar Terdampak Covid-19," ABDIPRAJA Jurnal Pengabdian Kepada Masyarakat) 1, no. 1 (2020): 107-15; Muhamad Uyun and Idi Warsah, "IAIN Curup Students' Self-Endurance And Problems In Online Learning During The Covid-19 Pandemic," Edukasi Islami: Jurnal Pendidikan Islam 10, no. 01 (February 20, 2021): 395-412, https://doi.org/10.30868/ei.v10i01.1211.

${ }^{6}$ Idi Warsah, "Islamic Religious Teachers' Efforts To Motivate Students And Implement Effective Online Learning," Edukasi Islami: Jurnal Pendidikan Islam 10, no. 01 (February 20, 2021): 383-94, https:// doi.org/10.30868/ei.v10i01.1210.

7 Handayani, Khasanah, and Yoshinta, "Pendampingan Belajar Di Rumah Bagi Siswa Sekolah Dasar Terdampak Covid-19.”

8 Andri Anugrahana, "Hambatan, Solusi Dan Harapan: Pembelajaran Daring Selama Masa Pandemi Covid-19 Oleh Guru Sekolah Dasar," Scholaria: Jurnal Pendidikan Dan Kebudayaan 10, no. 3 (n.d.): 282-89.

9 Idi Warsah and Fuad Nashori, "Model Of Everyone Is A Teacher Here: Solution To Build Up Students' Self-Confidence," Jurnal Psikologi Integratif 8, no. 2 (January 31, 2021): 1-17, https://doi.org/10.14421/jpsi.v8i2.2061; Warsah and Nuzuar, "Analisis Inovasi Administrasi Guru Dalam Meningkatkan Mutu Pembelajaran (Studi Man Rejang Lebong).” 
sebelumnya, dan sengaja diusahakan untuk meningkatkan kemampuan guna mencapai suatu tujuan dalam dunia pendidikan. ${ }^{10}$ Berdasarkan kutipan di atas, dapat diartikan pula bahwa inovasi pembelajaran adalah suatu usaha pembaharuan yang dilakukan dalam bidang pendidikan sehingga dapat menghasilkan proses pembelajaran yang lebih baik. Dalam dunia pendidikan, banyak inovasi pembelajaran yang dapat diterapkan dalam pembelajaran di masa pandemi covid-19 ini. Salah satunya yaitu dengan menerapkan inovasi pembelajaran multimodal dalam kegiatan pembelajaran.

Menurut Kress and Van Leeuwen, multimodal didefinisikan sebagai penggunaan beberapa mode semiotik dalam desain produk, atau peristiwa semiotik secara bersamaan, dan dengan cara tertentu mode-mode ini digabungkan untuk memperkuat, melengkapi, atau berada dalam susunan tertentu. ${ }^{11}$ Sementara itu Yumin Chen memaknai multimodal sebagai segala sumber semiotik verbal dan visual yang dapat digunakan untuk merealisasikan jenis dan tingkatan keterlibatan dialogis dalam sebuah buku teks ${ }^{12}$. Berdasarkan kedua pendapat tersebut di atas, dapat penulis artikan bahwa pembelajaran multimodal merupakan sebuah proses pembelajaran dengan memanfaatkan berbagai macam sumberdaya (tulisan, gambar, suara, gerakan, dan lain sebagainya) dengan tujuan untuk membantu siswa dalam mempelajari dan memahami sesuatu.

Oleh karena permasalahan di atas program Kuliah Kerja Nyata (KKN) ini difokuskan untuk memberikan layanan pendampingan belajar siswa pada masa pandemic covid-19, khusus di lingkungan RT 05 RW 03 Desa Jajag Kecamatan Gambiran Kabupaten Banyuwangi yang mengalami pembelajaran secara daring serta membutuhkan bantuan. Melalui program Kuliah Kerja Nyata (KKN) Institut Agama Islam (IAI) Ibrahimy Genteng Banyuwangi yang merupakan program pengabdian kepada masyarakat bagi dosen dan mahasiswa melakukan kegiatan "pendampingan belajar siswa melalui pembelajaran multimodal untuk meningkatkan kemampuan siswa di masa pandemi covid-19" dengan sasaran siswa SD/MI diharapkan proses pembelajaran daring berjalan lancar, serta mampu meningkatkan kemampuan belajar siswa serta dapat meringankan beban orang tua.

Kegiatan pengabdian ini dilakukan dengan cara sebagai berikut:

a. Persiapan

Pengabdian ini dilaksanakan dengan mendampingi belajar siswa terdampak covid-19. Sasaran pendampingan ini sebanyak 10 orang siswa usia sekolah dasar di lingkungan dusun Yosowinangun 05/03, desa Jajag,

${ }^{10}$ M. Sahibudin M. Sahibudin, "Peningkatan Mutu Pendidikan Islam Melalui Peningkatan Kreatifitas Pendidikan," Al-Ulum Jurnal Pemikiran Dan Penelitian Ke Islaman 5, no. 1 (February 21, 2018): 81-91, https://doi.org/10.31102/alulum.5.1.2018.81-91.

11 Taufiq Akbar Al Fajri, "Pentingnya Penggunaan Pendekatan Multimodal Dalam Pembelajaran,” Waskita: Jurnal Pendidikan Nilai Dan Pembangunan Karakter 2, no. 1 (2020): 57-72.

12 Yumin Chen, "Exploring Dialogic Engagement with Readers in Multimodal EFL Textbooks in China," Visual Communication 9, no. 4 (2010): 485-506. 
kecamatan Gambiran, kabupaten Banyuwangi pada bulan Agustus hingga September 2020. Para siswa tersebut berasal dari sekolah yang berbeda yaitu Madrasah Ibtidaiyah Negeri 3 Jajag dengan jumlah 2 orang siswa dan Sekolah Dasar Negeri 1 jajag dengan jumlah 8 orang siswa. Sebelumnya, tim melakukan kegiatan observasi terlebih dahulu terhadap kegiatan belajar anakanak di lingkungan dusun Yosowinangun RT 05 RT 03 Desa Jajag. Tim juga melakukan wawancara dengan siswa dan orang tuanya serta mengamati lingkungan belajar siswa sasaran. Berdasarkan hasil observasi dan wawancara ditemukan beberapa permasalahan utama yang ditemukan antara lain: 1) Orang tua siswa tidak mampu mendampingi belajar anaknya, 2) Siswa kurang mampu memahami materi pelajaran secara mandiri, 3) Dukungan fasilitas yang kurang memadai, 4) Beberapa siswa dan orang tua tidak dapat mengoperasikan gadget dan ada siswa yang tidak memiliki gadget sehingga menghambat dalam mengikuti pembelajaran secara daring.

Table 1. Peserta Pendampingan Belajar

\begin{tabular}{|c|l|c|c|}
\hline NO & \multicolumn{1}{|c|}{ NAMA } & SEKOLAH & KELAS \\
\hline 1. & April Alfi Mukaromah & MI Negeri 3 Jajag & 3 \\
\hline 2. & Salsabila & MI Negeri 3 Jajag & 3 \\
\hline 3. & Fenita Indriyani & SD Negeri 1 Jajag & 3 \\
\hline 4. & Agsyah Alifatul & SD Negeri 1 Jajag & 3 \\
\hline 5. & Citra Bunga Lestari & SD Negeri 1 Jajag & 4 \\
\hline 6. & Novia Dwi Nur Solekhah & SD Negeri 1 Jajag & 4 \\
\hline 7. & Syifa Tahta A.H & SD Negeri 1 Jajag & 4 \\
\hline 8. & Aurelia Zora Anditi & SD Negeri 1 Jajag & 5 \\
\hline 9. & Rizki Putri Suryaningrum & SD Negeri 1 Jajag & 5 \\
\hline 10. & Merliana Nasya Safitri & SD Negeri 1 Jajag & 5 \\
\hline
\end{tabular}

Konsep pembelajaran multimodal dipilih sebagai salah satu upaya untuk memecahkan masalah belajar dan mengasah kreatifitas siswa secara mandiri dengan memanfaatkan berbagai mode (media) atau teknologi yang digabungkan menjadi satu kesatuan yang bermakna. Pembelajaran multimodal dalam pengabdian ini ditekankan pada penggabungan dari beberapa mode. Pelaksanaan pembelajaran multimodal diaplikasikan dalam bentuk kegiatan berupa kegiatan bercerita, menghafal kosa-kata, serta kegiatan membuat video pembelajaran.

b. Metode Pelaksanaan

\section{Perencanaan}

Tahap ini dilakukan dengan cara merencanakan kegiatan yang akan dilakukan, dengan memperhatikan hasil observasi tim pelaksana maka program yang dibentuk adalah pendampingan belajar siswa selama masa 
pandemi covid-19. Tim memperkenalkan dan menjelaskan identitas diri, konsep dan tujuan pelaksanaan program, serta tata cara pelaksanaan program pendampingan belajar yang akan dilaksanakan.

Selanjutnya penyusunan jadwal kegiatan pelaksanaan pendampingan belajar. Siswa yang mengikuti program di Dusun Yosowinangun RT 05 RW 03 Desa Jajag Kecamatan Gambiran ini didampingi oleh 1 orang mahasiswa yang berasal dari Program Studi Pendidikan Guru Madrasah Ibtidaiyah Institut Agama Islam (IAI) Ibrahimy Genteng Banyuwangi dengan frekuensi 3 kali pertemuan dalam seminggu dan dilaksanakan selama 4 pekan.

Pendampingan

Kegiatan pendampingan dilaksanakan dalam bentuk pendampingan aktifitas belajar mengajar mulai dari kegiatan membaca, menulis, menghafal, bercerita, dan praktik dengan memanfaatkan berbagai macam media pembelajaran antara lain teks, gambar, audio, video, serta perangkat teknologi informasi dan komunikasi.

\section{c. Tahap Evaluasi}

Tahap evaluasi dilakukan untuk melihat tingkat keberhasilan kegiatan mulai dari persiapan, tahap pelaksanaan, hingga capaian hasil kegiatan. Partisipasi siswa sasaran dalam pelaksanaan program ditunjukkan dengan adanya dokumentasi saat pendampingan berlangsung. Evaluasi terhadap siswa sasaran pendampingan dilakukan setiap satu minggu sekali guna mengetahui kekurangan dan solusi memperbaikinya kekurangan.

\section{Hasil dan Pembahasan}

Kegiatan yang pertama dilakukan adalah mendampingi siswa dalam belajar. Materi yang diajarkan oleh tim pengabdi yaitu materi pelajaran sesuai dengan mata pelajaran yang ada di kelasnya masing-masing, khususnya mata pelajaran matematika dan IPA karena banyak siswa sasaran yang mengalami kesulitan memahami materi secara mandiri. Selain itu siswa juga dibimbing bagaimana cara menggunakan media pembelajaran whatsapp group yang digunakan oleh sekolah selama pembelajaran dari rumah, cara mengakses berbagai referensi sumber belajar yang berasal dari internet. Proses pendampingan belajar mandiri kepada siswa sasaran berjalan dengan baik dan lancar. Hasil yang diperoleh dari pendampingan belajar mandiri ini terlihat cukup baik. Siswa merasa bersemangat dan antusias selama proses pendampingan belajar dan merasa terbantu dalam menyelesaikan tugas dari sekolah.

Tingginya semangat dan antusiasme siswa sasaran dalam mengikuti pendampingan ini memungkinkan materi yang dipelajari diserap dengan baik. Siswa sasaran menjadi lebih mudah memahami materi dibanding saat belajar secara mandiri. Hal tersebut ditunjukkan saat siswa mampu mengerjakan tugas dengan baik setelah diberikan penjelasan oleh tim pelaksana pengabdian. Respon siswa sasaran setelah mengikuti pendampingan ini menyatakan tidak 
lagi asing dan menjadi terbiasa dalam menggunakan media belajar whatsapp group dan mengakses referensi sumber belajar dari internet.

Kegiatan selanjutnya adalah bercerita. Kegiatan bercerita ini bertujuan untuk melatih kemampuan mengingat dan melatih rasa percaya diri siswa sasaran. Kegiatan bercerita yang dilakukan dalam pengabdian ini bukan hanya menceritakan kembali sebuah cerita yang ada di dalam buku, tetapi lebih kepada untuk melatih kemampuan mengingat dan menguatkan metakognisi siswa sasaran melalui kognitif proses (Cognitive process). Kegiatan ini dimulai dengan menampilkan video kepada siswa sasaran sebagai rangsangan agar siswa sasaran memahami bagaimana cara membuat cerita dan membacakan cerita dengan baik. Cara ini efektif diberikan kepada siswa sasaran, yang menunjukkan bahwa terdapat sekitar 90\% dari informasi yang diterima siswa sasaran dari dunia luar untuk bertahan dan berkembang dalam bentuk visual. Karena pada dasarnya, manusia memiliki kemampuan untuk memproses gambar 60.000 kali lebih cepat daripada teks biasa. Setelah memperlihatkan video, penulis memberikan contoh cara menulis cerita dan membacakan cerita sebagai penguat dari video yang diberikan sebelumnya.
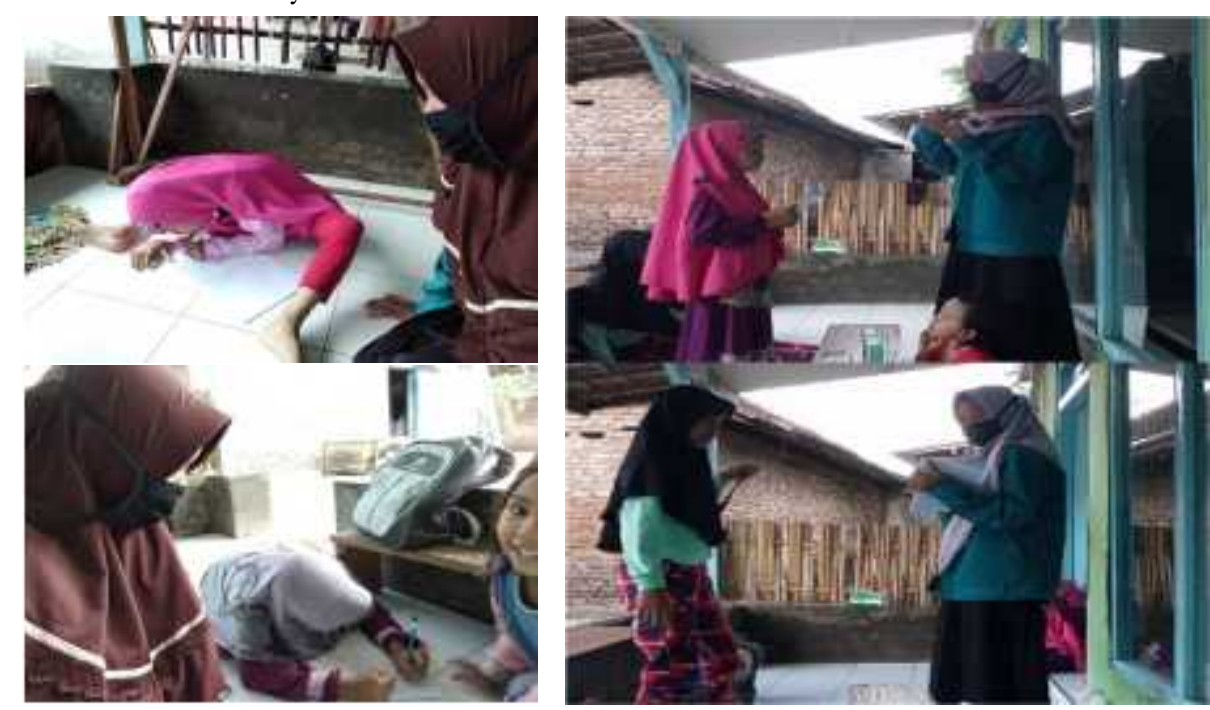

Gambar 1. Peserta pendampingan (siswa) membuat cerita dan membacakannya kembali

Dalam kegiatan bercerita ini terlihat pada Gambar 1, siswa sasaran diminta untuk membuat cerita dengan tema yang berbeda sesuai dengan pengalamannya sendiri-sendiri. Kemudian, siswa sasaran juga diberikan kesempatan untuk bercerita dihadapan temannya. Hal ini dilakukan untuk melatih rasa percaya diri siswa sasaran untuk tampil di depan orang lain.

Kegiatan berikutnya bertujuan untuk memperkaya perbendaharaan kosa kata siswa sasaran. Kegiatan tersebut yaitu menghafal kosa kata. Kosa kata yang dihafalkan siswa tidak hanya terpaku pada satu bahasa saja, tetapi terdiri dari beberapa bahasa diantaranya yaitu bahasa inggris, bahasa arab, bahasa 
Indonesia, dan bahasa jawa. Pemberian materi kosa-kata tidak diberikan secara serta merta pada satu waktu. Dalam pelaksanaannya, pemberian kosa kata dilakukan secara bertahap di hari yang berbeda dan dibantu dengan penggunaan media audio (suara) sehingga siswa sasaran merasa senang.

Pemberian materi menghafal kosa kata tidak hanya bertujuan untuk memperkaya kosa kata siswa sasaran saja, tetapi juga untuk melatih kreativitasnya karena pada kegiatan ini, siswa sasaran dilatih untuk menghafal kosa kata dengan mengaransemen sebuah lagu (mengganti lirik sebuah lagu dengan kosa kata yang dihafalkannya).

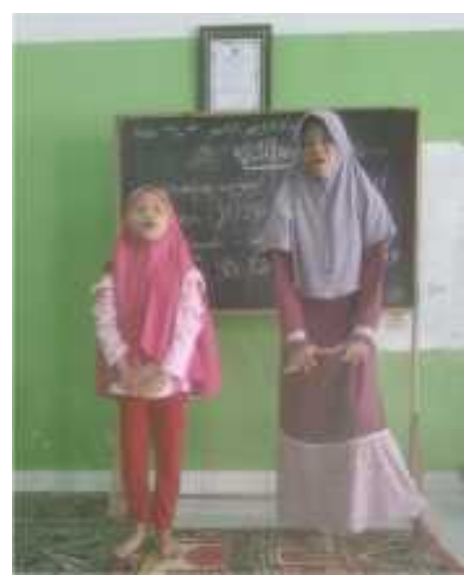

Gambar 2. Menghafal kosa kata melalui lagu

Setelah mengaransemen lagu menggunakan kosa kata baru, siswa sasaran diberi kesempatan untuk menampilkan hasil aransemennya disertai dengan gerakan yang sesuai. Karena kondisi pandemi ini, siswa sasaran diminta untuk memvideokan kegiatan belajar mereka untuk diperlihatkan kepada temantemannya. Kegiatan ini bertujuan untuk melatih kepercayaan diri siswa sasaran untuk tampil di hadapan orang lain seperti yang terlihat pada gambar di atas.

Kegiatan ini juga bertujuan untuk mengembangkan kreativitas siswa dalam berbicara, melatih rasa percaya diri siswa, dan membiasakan siswa untuk gemar berbagi ilmu. Kegiatan tersebut yaitu pembuatan video pembelajaran. Dalam video pembelajaran ini, penulis memberikan stimulus dengan menampilkan video pembelajaran melalui telepon pintar.

Hal ini diperkuat dengan hasil penelitian Faishol dkk (2021), yang menunjukkan bahwa dengan memanfaatkan media film/video dalam aktivitas pembelajaran mampu memudahkan siswa dalam memahami dan menghafal materi yang sedang dipelajari. ${ }^{13}$ Kemudian siswa diberikan sebuah contoh teks

13 Riza Faishol, Ahmad Izza Muttaqin, and Mohammad Afton Fahmi Prayogie, "Penggunaan Media Pembelajaran Film Dokumenter Pada Mata Pelajaran Sejarah Kebudayaan Islam (Ski) Kelas VIII C di MTs Kebunrejo Genteng Banyuwangi," Tarbiyatuna: Kajian Pendidikan Islam 5, no. 1 (2021): 40-54. 
percakapan berbahasa asing sebagai konten video pembelajarannya. Setelah pemberian contoh teks percakapan tersebut, siswa diminta untuk membuat sendiri teks percakapan sederhana menggunakan bahasa asing.

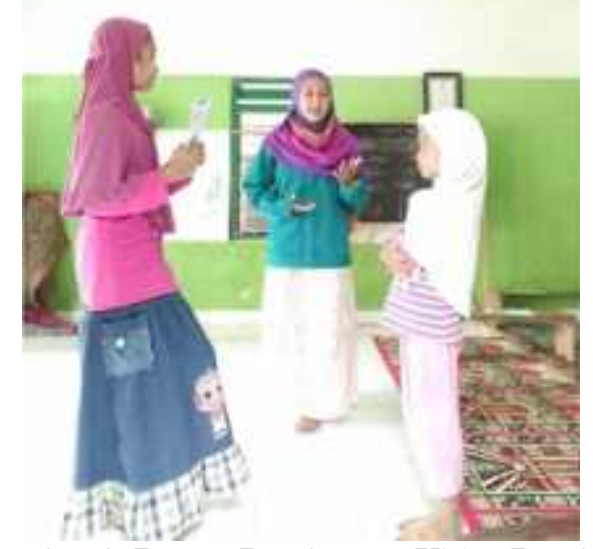

Gambar 3. Proses Pembuatan Video Pembelajaran

Seperti pernyataan Moore and Caldwell dalam Hutchison \& Hornsby dalam Kartika Nuswantara bahwa kreatifitas dapat ditumbuhkan dengan menginterkoneksikan antara karya seni dan pembelajaran bahasa. ${ }^{14} \mathrm{Hal}$ tersebut didukung hasil penelitian Faishol dkk, yang menyatakan bahwa pembelajaran dengan memanfaatkan media audio visual (video) terbukti efektif untuk melatih siswa dalam berbahasa asing. ${ }^{15}$ Gambar di atas (Gambar 5) menunjukkan pada saat siswa sasaran sedang melakukan proses pembuatan video pembelajaran.

Video pembelajaran ini merupakan implementasi dari pengembangan keterampilan yang menstimulasi berkembangnya Higher-Order Thingking Skills (HOTS) seperti yang dipopulerkan oleh Bloom. Ini merupakan representasi kemampuan tingkat tinggi dimana siswa mampu menghasilkan karya sebagai hasil kegiatan pembelajaran.

Dengan adanya inovasi pembelajaran multimodal ini, terbukti dapat membantu siswa sasaran yang sebelumnya pendiam, pemalu, serta kurang percaya diri. Setelah mengikuti proses pendampingan ini siswa sasaran tersebut menjadi lebih aktif, kreatif, dan memiliki rasa percaya diri yang tinggi. Tidak hanya itu, orang tua siswa sasaran juga merasa senang dan sangat terbantu karena dapat meringankan tugas orang tua dalam membimbing belajar anaknya.

Kendala yang ditemui dalam pelaksanaan program pengabdian ini adalah tidak semua siswa sasaran memiliki fasilitas berupa handphone dan paket

\footnotetext{
${ }^{14}$ Kartika Nuswantara, "Photo-Voice: Optimalisasi Peran Taman Baca Masyarakat (TBM) Sebagai Sarana Penguatan Literasi Danpengembangan Laboratorium Pembelajaran Sepanjang Hayat," IPTEK Journal of Proceedings Series, no. 5 (2018): 90-97.

${ }^{15}$ Riza Faishol and Imam Mashuri, "Pengaruh Media Audio Visual Terhadap Hasil Belajar Bahasa Inggris Siswa Kelas 2 Mi Tarbiyatus Sibyan Srono," INCARE, International Journal of Educational Resources 1, no. 6 (2021): 523-40.
} 
data, sehingga menghambat aktivitas belajar siswa. Strategi untuk mengatasi kendala ini dengan cara menambah perangkat elektronik yang digunakan oleh tim pengabdian yaitu dengan penambahan perangkat bandphone dan memanfaatkan laptop tim pengabdi. Pada akhir kegiatan pengabdian, dilakukan evaluasi bersama dengan tim pelaksana pengabdian serta dosen pembimbing terkait kinerja dan program yang telah berjalan. Evaluasi ini dilakukan agar program kegiatan pendampingan belajar dapat berjalan dengan lancar dan lebih baik lagi.

\section{Penutup}

Rangkaian kegiatan pengabdian pendampingan belajar di Dusun Yosowinangun RT 05 RW 03 Desa Jajag Kecamatan Gambiran Kabupaten Banyuwangi ini secara umum berjalan dengan lancar. Hal ini karena sebagian besar siswa sasaran telah mampu menuntaskan kegiatan belajar dari rumah, mampu menyelesaikan tugas dari sekolah dengan baik, dan mampu memahami materi yang diterimanya saat pembelajaran online. Pembelajaran multimodal yang diberikan melalui kegiatan yang melibatkan aspek sikap, pengetahuan dan keterampilan secara bersamaan mendorong anak memiliki daya kreativitas yang tinggi dan mampu mengikis rasa tidak percaya diri siswa sasaran. Melalui kegiatan bercerita, menghafal kosa kata dan membuat video pembelajaran, siswa memiliki peluang besar untuk lebih berprestasi, kreatif dan mandiri ketika belajar dari rumah saat pandemi berlangsung. Kegiatan-kegiatan yang dimodelkan oleh tim pengabdian telah mengintegrasikan kemampuan kognitif, afektif, dan psikomotorik siswa. Sehingga pada saat yang sama mampu mendorong anak untuk lebih aktif, kreatif dan percaya diri.

\section{Daftar Pustaka}

Al Fajri, Taufiq Akbar. "Pentingnya Penggunaan Pendekatan Multimodal Dalam Pembelajaran." Waskita: Jurnal Pendidikan Nilai Dan Pembangunan Karakter 2, no. 1 (2020): 57-72.

Andrianto, Andrianto. "Implementasi Komunikasi Edukatif dalam Pemaduan Iman, Ilmu dan Amal Studi Pembelajaran PAI di SMA IT Abu Bakar Yogyakarta." Tarbiyatuna: Kajian Pendidikan Islam 3, no. 2 (September 29, 2019): 89-105. https://doi.org/10.29062/tarbiyatuna.v3i2.261.

Anugrahana, Andri. "Hambatan, Solusi dan Harapan: Pembelajaran Daring Selama Masa Pandemi Covid-19 Oleh Guru Sekolah Dasar." Scholaria: Jurnal Pendidikan Dan Kebudayaan 10, no. 3 (n.d.): 282-89.

Chen, Yumin. "Exploring Dialogic Engagement with Readers in Multimodal EFL Textbooks in China." Visual Communication 9, no. 4 (2010): 485506.

Elisvi, Julia, Rafia Archanita, Deri Wanto, and Idi Warsah. "Analisis Pemanfaatan Media Pembelajaran Online Di SMK IT Rabbi Radhiyya 
Masa Pandemi Covid-19." Al-Tarbawi Al-Haditsab: Jurnal Pendidikan Islam 5, no. 2 (December 17, 2020). https://doi.org/10.24235/tarbawi.v5i2.6721.

Faishol, Riza, and Imam Mashuri. "Pengaruh Media Audio Visual Terhadap Hasil Belajar Bahasa Inggris Siswa Kelas 2 MI Tarbiyatus Sibyan Srono." INCARE, International Journal of Educational Resources 1, no. 6 (2021): 523-40.

Faishol, Riza, Ahmad Izza Muttaqin, and Mohammad Afton Fahmi Prayogie. "Penggunaan Media Pembelajaran Film Dokumenter Pada Mata Pelajaran Sejarah Kebudayaan Islam (SKI) Kelas VIII C di Mts Kebunrejo Genteng Banyuwangi." Tarbiyatuna: Kajian Pendidikan Islam 5, no. 1 (2021): 40-54.

Handayani, Tri, Hariyani Nur Khasanah, and Rolisda Yoshinta. "Pendampingan Belajar Di Rumah Bagi Siswa Sekolah Dasar Terdampak Covid-19." ABDIPRAJA (Jurnal Pengabdian Kepada Masyarakat) 1, no. 1 (2020): 10715.

Krismawati, Krismawati, Idi Warsah, and Ummul Khair. "Implementasi Pendekatan Kontekstual dalam Pembelajaran PAI di Sekolah Dasar." Jurnal Elementaria Edukasia 3, no. 2 (October 22, 2020). https://doi.org/10.31949/jee.v3i2.2262.

Nuswantara, Kartika. "Photo-Voice: Optimalisasi Peran Taman Baca Masyarakat (TBM) Sebagai Sarana Penguatan Literasi Danpengembangan Laboratorium Pembelajaran Sepanjang Hayat." IPTEK Journal of Proceedings Series, no. 5 (2018): 90-97.

Sahibudin, M. Sahibudin M. "Peningkatan Mutu Pendidikan Islam Melalui Peningkatan Kreatifitas Pendidikan." Al-Ulum Jurnal Pemikiran Dan Penelitian Ke Islaman 5, no. 1 (February 21, 2018): 81-91. https://doi.org/10.31102/alulum.5.1.2018.81-91.

Tamara, Jessika, Sugiatni Sugiatni, Eka Yanuarti, Idi Warsah, and Deri Wanto. "Strategi Pembelajaran Dosen Melalui Pemanfaatan Media Whatsapp Di Masa Pandemi COVID-19." At-Ta'lim : Media Informasi Pendidikan Islam 19, no. 2 (December 30, 2020): 351-73. https://doi.org/10.29300/attalim.v19i2.3372.

Uyun, Muhamad, and Idi Warsah. "IAIN Curup Students' Self-Endurance And Problems In Online Learning During The Covid-19 Pandemic." Edukasi Islami: Jurnal Pendidikan Islam 10, no. 01 (February 20, 2021): 395-412. https://doi.org/10.30868/ei.v10i01.1211.

Warsah, Idi. "Islamic Religious Teachers' Efforts To Motivate Students And Implement Effective Online Learning." Edukasi Islami: Jurnal Pendidikan Islam 10, no. 01 (February 20, 2021): 383-94. https://doi.org/10.30868/ei.v10i01.1210. 
_. "Pendidikan Keimanan Sebagai Basis Kecerdasan Sosial Peserta Didik: Telaah Psikologi Islami." Psikis: Jurnal Psikologi Islami 4, no. 1 (2018): 1 16.

Warsah, Idi, and Fuad Nashori. "Model Of Everyone Is A Teacher Here: Solution To Build Up Students' Self-Confidence." Jurnal Psikologi Integratif 8, no. 2 (January 31, 2021): 1-17. https://doi.org/10.14421/jpsi.v8i2.2061.

Warsah, Idi, and Nuzuar Nuzuar. "Analisis Inovasi Administrasi Guru Dalam Meningkatkan Mutu Pembelajaran (Studi Man Rejang Lebong)." Edukasi 16, no. 3 (2018): 294572. 